\title{
Crossing the Pale \\ Representations of White Western Women in Indian Film and Media
}

\author{
Transforming Cultures eJ ournal, \\ Vol. 3 No 1, February 2008 \\ http:// epress.lib.uts.edu.au/journals/TfC
}

\section{Jann Dark ${ }^{1}$}

\begin{abstract}
In this paper I focus on the way the white Western woman is scripted into two recent Indian films, and show how colonial discourses still affect the way she is represented today in Indian media. More than just a simple plot device, her usevalue in partnership or sexual relations to the Indian male protagonist, rests upon two points: one, the power she represents due to her position as a signifier of Western economic forces, two, her projection as seductress and victim in colonialist discourses that characterised the Indian male as effeminate and rapacious of English women. The films I will discuss are: Lagaan: Once Upon a Time in India (Dir.Ashutosh Gowariker, 2001) and Rang de Basanti: A Generation Awakens (Dir.Rakeysh Omprakesh Mehra, 2006). I will also look at an advertisement for an Indian clothing company.

The white Western woman represents concerns in Indian society about the place of Indian women in modernity and processes of Westernisation. Ideas of nationhood, constructions of masculinity and national unity have been made dependent upon the way the white woman's influence is controlled and how her image is used. The characterisation of the white woman in these films is instrumental to these issues in two ways. She can enhance the power and sexual kudos of Indian masculinity. Second, she is used to provoke and confirm selective adoptions of modernity, which specifically directs how Indian women will be modern and what choices they have.
\end{abstract}

\section{Introduction}

A dialogue about women and sex has long adorned military, political and cultural relationships between West and East. Imaginings, observations and curiosity about women as 'types', how they are different, what they will do sexually and what can be done with them, have been used as stereotyping propaganda, entertainment and for

\footnotetext{
${ }^{1}$ Jann Dark has a Doctorate in Creative Arts from the University of Western Sydney.
} 
cultural, intellectual and scientific ‘investigations’ (Schick, 1999:230). Women often come to represent contesting differences between groups. Questions of morality hinge upon the behaviors of women rather than men, and are used in racist and communalist discourses aimed at creating an unacceptable and alien 'other', made more 'other' by the imagined complete otherness of their women folk. ${ }^{2}$ This paper is conceived with this understanding of how the characterisations of women as symbolic carriers of cultural agendas are played out in cultural and representational forms.

Despite a popular notion in the West that we are in a post-feminist era, women's image is still used as a form of emotional currency to activate and capitalise on fear and desire about gender identity and adequacy. Griselda Pollock stresses the importance of understanding that representations of women in media carry ideology that relate to gender relations in social life (Pollock, 1987:133). This is particularly true of the films I discuss in this paper, which belong to the genre of Indian film known as Bollywood. In these films, female characters tend to conform to the culturally enshrined roles of mother, wife and daughter in which the woman accepts her position of service to family, father and husband. Or she will attach herself to a social rebel or outcast and support his quest for justice or retribution. This reflects an ideological position in India in which women are culturally and symbolically linked to the home, while men are associated with being outside, in the social world. Woman as mother is idealised as the protector of Indian culture and tradition. Upholding and controlling the integrity of traditional female roles centered around the stability of the family home, has been seen as an essential component of maintaining both national and masculine identity.

In India, women carry a complex collection of responsibilities and expectations. This complexity is found in the deep respect often given to women who fulfill the expectations of their family, compared to the terrible retribution and neglect frequently meted out to women who act against the wishes of their families. A further complication for women exists in the conflict between modernity and Westernisation. Broadly, two societies exist and intermingle in India. One is modern with a growing taste for

\footnotetext{
2 The furore in 2006 over the alleged statements of the Muslim Mufti of Australia, Sheik Taj el-Din al Hilaly, linking rape with immodest dress, show how volatile the issue of women and morality is. Quoting an Islamic scholar, Hilaly stated that, "if she hadn't left the meat uncovered, the cat wouldn't have snatched it”. Allard, T. et al. 'Muslims set to dump defiant Hilaly'. The Sydney Morning Herald, 28th29th October 2006. p 1. Similarly the panic over Muslim women wearing veils is seen as a threat to Western democracy, secular society and gender equality.
} 
Westernisation that allows some women of middle and upper class families more choices in life. The other is traditional India, found in the villages with some presence in the cities, where change is slower and it is more difficult for women to exercise choice. Often a distinction is made between modernity and Westernisation (Ghosh in Brosius, 1999:248). Westernisation has aroused community fears about its influence on the perversion of female morality in contemporary India. ${ }^{3}$

\section{Women compared and contrasted}

In The White Women's Other Burden, Kumari Jayawardena shows how the white woman played two broad roles in Indian popular conception during the campaign for independence. She was represented as either an example of the immorality and decadence of the West or respected for her support of the Independence Movement and Indian, particularly Hindu, tradition and spirituality (Jayawardena, 1995:8). It is clear, from the long history of popular Hindi film, that the white or Westernised woman has embodied conflicts about modernity and Westernisation in Indian communities.

Until recently, white or Westernised women have been portrayed in Bollywood cinema as vamps, usually played by Eurasian women (Gokulsing and Dissanyake, 1998:77). The vamp, although loved by her audience, was always held outside moral and respectable ideals of Indian femininity. The vamp role echoes Western Orientalist fantasies and fears that placed the white European woman into erotic, exotic or rapacious scenes with the Asian or Eastern male. Putting the white woman into such a scene held particular fascination for the European male. A print by Thomas Rowlandson (1756-1827) shows an Eastern man enjoying the sight of a gallery of naked white women (Schick, 1999: xii). He is holding a long smoking pipe on his knee with its mouthpiece pointing directly to his erect penis.

The use of sexuality and desire as part of the arsenal of colonial power is well documented. Michel Foucault observed that sexuality, rather than being a private and

\footnotetext{
3 Sohini Ghosh in her essay, 'Feminists Engage with Censorship', records the conflict over the staging of Miss World, 1996 in Bangalore, as being a protest against Westernisation. A prominent Hindu fundamentalist protester stated that they 'were not against being modern, but being Western.' See, Brosius, C, Butcher, M. 1999:248. In 2005, a prominent actress sparked angry demonstrations in Chennai for suggesting that 'an educated male should not expect his bride to be a virgin.' See Radhakrishna,G.S. et al, 'Whose a Virgin These Days?' At www.telegraphindia.com/1051204/asp/others.html (5/1/06)
} 
negligible issue in power relations is actually one of the most useful 'instruments', as he puts it, 'for the greatest number of manouvres and [is] capable of serving the most varied strategies' (in Schick, 1999:1). The image of the white woman in transit West to East, East to West, forms part of the 'media ecology' of India. Her role is not incidental, just as the roles of Indian women are not incidental to constructions of nationhood and traditional culture. In India, in response to colonial and Orientalist stereotyping, the white Western woman and the Indian woman operate in tandem as oppositional structures consolidating notions of Indianess and traditional values. Partha Chatterjee delineates the complex way that the middle class Indian woman is selectively emancipated and admitted into pre and post-independence processes of modernity and nation building. She must above all be different from the white modern English and Westernised woman. She can take part in modernity but must maintain Indian traditions of femininity, modesty, devotion and self-sacrifice. Chatterjee suggests that she is desexualised as Mother and Goddess and counterpoised as 'normal' against the 'abnormality' of 'those who could be sex objects' (Chatterjee, 1993:131-132).

As she 'who could be sex object', the image of the white woman has operated as a sexual conscript in the structuring of desires. She is seen in advertisements and other popular media all over India which associate her with consumer wealth and Western lifestyles. She is part of the bricolage of colonial and postcolonial globalising capitalist culture/s. In the following pages I will show how her characterisation in Lagaan, Rang de Basanti and the advertisement use her as a locus of power that expresses a desire to control the choices Indian women can exercise in modernity. Her sexual use strategically operates at the expense of the Indian woman, supplanting the Indian woman or re-enforcing restrictive gender constructs. The white woman serves the interests of a hyper and insecure masculinity recalling aspects of nationalism that originated with the denigrations of colonialism.

\section{Lagaan}

The Indian film maker K Hariharan claims that until Lagaan, Indian films featuring white women in central roles were not successful 'either commercially or artistically' (2002:2). The roles these women played were not vamp roles, although the possibility of sexual relations with the Indian male protagonist was often present. They were 
'adamantly disciplined' women who to varying degrees 'critiqued the Indian system' (Hariharan, 2002: 2).

Recently Indian films have depicted the white woman in a facilitative role, as an ally to the main protagonist of the film and to broader local and national interests. These films have been successful, perhaps picking up on perceptions of the supportive 'white sister' role present during the British Raj. Two of these films are Lagaan and Rang de Basanti.

Lagaan (in Hindi, tax) is historically set in colonial India (1893) in a fictitious garrison town. During a drought, the tyrannical English commander, Captain Russell, imposes a bet on the villages under his control. They must play a game of cricket against the English garrison. If the Indians lose they will be expected pay three times the year's tax. Captain Russell's sister, Elizabeth, seeing the unfairness of her brother's actions, offers to teach the Indians how to play the game. In doing this she enables them to win and avoid both the tax and the humiliation that the Captain was obviously most interested in achieving. She, however, also falls in love with the Indian hero of the story, Bhuvan. Her love remains unrequited for the rest of her life. At the end of the film a voice over informs us that she goes home to England and never marries, but remains 'Bhuvan's Radha’ forever. Bhuvan himself marries his village sweetheart, Gauri.

With the exception of Grant Farred, reviewers of this film have neglected to explore the role of the white woman. Farred sees Elizabeth and Gauri as pivotal to the carriage of contemporary meaning throughout the film. He highlights the pedagogical role not only of Elizabeth, but Gauri as well. Elizabeth offers a cultural education. Gauri's role is 'anticipatory, mediating - deploying the Bollywood romance genre as a trope for and of national imaging' (Farred, 2004:95-96). The pairing of Elizabeth and Gauri in a love contest provides a focus for the expression of contemporary Hindu nationalist concerns over purity of race (ibid: 109).

Farred suggests that Lagaan can be read as a 'double temporality', a story that is set in the past but is making a direct comment to national concerns in the present (ibid: 93). If we read Lagaan in this way, the presence of the white woman, her role in the story and her subsequent treatment raise interesting questions. From today's point of view, why is it attractive to have an English woman teach the Indians how to play cricket? 
To answer this question, I must extend Farred's argument and follow the way Elizabeth beneath her 'pedagogical role', is constructed as other, as 'abnormal' in Chatterjee's sense. Masculine identity, power and sexual kudos, the maintenance of traditional gender relations, economic and national independence, unity, purity of race, all depend on using, controlling and rejecting this dangerous other.

The first we see of Elizabeth is of a self-effacing strong character, sensitive and polite, well trained in social graces, very good and 'fair'. When she first meets Bhuvan and the villagers, Farred's 'double temporality' becomes apparent. The camera playing full on Elizabeth's face shows a not-so innocent Elizabeth, just for a moment. She appraises Bhuvan. Whereas Gauri's love for Bhuvan is innocent, Elizabeth's expression is knowing. Admiration on a sexual level is clear. At this moment the contemporary enters the film and Elizabeth doubles as the Western modern woman. Desire for Bhuvan slips into her good intentions but never completely dominates her. It is there, however, for the audience to play with. In the process of identifying with Bhuvan, the male audience can enjoy being between two women who desire them/him.

It is through the expressions and actions of the two women, Gauri and Elizabeth, that we see the play of desire that empowers the male gaze. Spectatorship is more complex than that conceptualised by Laura Mulvey in her study of Hollywood narrative film, in which she understood the gaze to be actively masculine (1989:25). In Lagaan the gaze is collective as well as hierarchical. It gives priority to the male gaze as subject, while the feminine is made object to be enjoyed. However, despite this, the women in the film are not passive, although strongly constrained within set roles. Importantly, the collective gaze includes the female audience as a vital member of the national family. The Indian female gaze is drawn into the pleasures of a heterosexual masculine gaze. They are invited to enjoy their own innings and eventual success in the competition between Elizabeth and Gauri for Bhuvan's love and the subsequent rejection and embalmment of the powerful Elizabeth in unrequited love. This process may proceed via the only way that Mulvey suggests that women can partake in patriarchy. The woman places her own desires for power and autonomy onto the male subject; she lives through him, associating herself with his success. He becomes her prize (ibid: 14). The white woman as audience is given the curious position of observing herself represented as both catalyst and bystander. This is made apparent when she is excluded from celebrating 
victory with the Indians. ${ }^{4}$ It is Elizabeth's presence and treatment that gives Indian women some power but limits it within clearly drawn boundaries.

In the space outside the village where the cricket lessons are to take place, the villagers are waiting for the white lady. This waiting is imbued with pregnant anticipation and the fear that she might not come. There is near silence and no music in the thorny barren landscape. Just as a young boy states that the goree, white lady, has not appeared, Gauri comes with food. Bhuvan snaps derisively at Gauri as she announces that she has arrived, having mistaken goree for her name. Bhuvan says 'Gauri nahi, goree...' subtitled, 'not a lassie, a lady'. In Hindi, however, gora simply means white man with the added 'ee' indicating feminine gender, with no reference to the more polite sounding English 'lady'. Gora is often used derisively. Whereas, Gauri is named after the unmarried goddess Parvati, who practices severe penance to win Shiva for her husband. She is worshipped by unmarried girls and represents purity and austerity.

The love conflict that is emerging between Elizabeth and Gauri is confirmed to the audience when Gauri asks 'why is a white witch wanting to teach them the game of cricket' and the boy answers 'because she took a fancy to Bhuvan'. As the carriage rounds the base of the hill into sight, the soundtrack resumes in a sinuous questioning refrain. A fluting, single note falls into a low drone when the camera focuses on Gauri's alert face as she moves to the front of the band of men, watching Elizabeth's arrival. As Elizabeth gets out of the carriage and walks towards the group the music loops and trills on a higher note. At this point the camera lingers on one of the waiting men, Goli. His face has an expression that is almost lascivious, mouth slightly open so that his tongue can be seen between his lips as he watches Elizabeth.

Gauri is very alert to the possible threat that Elizabeth might represent to Bhuvan's love for her. This is presented in the film as her own feminine weakness, her jealousy, as Bhuvan apparently remains innocent of Elizabeth's love and desire for him. While Bhuvan firmly anchors the film with his focus on winning the game, the audience can imagine other scenes, other fantasies, placing each viewer in a position of power that might, if acted out in life, be destructive and destabilising. Here, Farred's notion of

\footnotetext{
4 This is not to suggest that all viewing responses in the audience will follow the prompts of the film, only to outline how the film seems to invite identification.
} 
'double temporality' can be seen to extend beyond places in historical time and move into parallel texts or media. We are watching a film that would be billed as family entertainment, but for Goli's expression which could lead the viewer in a different direction. The film covertly accesses, via the viewer's imagination, more sexually explicit texts and images. Elizabeth's high standing, laced up goodness is shadowed by the possibility that she is also a whore. The scene where Gauri and Bhuvan declare their love is interspersed with scenes of Elizabeth, realising her love for Bhuvan to herself alone. There is a surprising moment when the editing suddenly puts Elizabeth in Gauri's place, so that what is really happening between Bhuvan and Gauri is invaded by Elizabeth's fantasy. This gives the sense that Bhuvan for that moment is not in control, that Elizabeth's desire could cut through his purity and innocence. In these scenes the film gives the audience the opportunity to imagine themselves or Bhuvan transgressing a moral boundary.

Through Bhuvan's victory and rejection of the white woman's desire, the community in the film and the audience can achieve unity. Nation-wide fears to do with sectarian, caste and political tensions are abated in the imagined community/nation of the film. The rejection of the 'bad' white woman is important for the plot as a test or tapas (sanskrit for austerity and discipline) to masculine discipline. The combined 'he' as audience and Bhuvan, representative of Indian/Hindu heroism, can prove its allegiance to nation and protect racial purity.

Most importantly, the white woman is set up in sexual competition with the Indian woman for the affections of the main character. Echoing Chatterjee's thesis, Gauri's role is clearly ‘woman as a sign of nation’ (Chatterjee, 1993:131). Elizabeth and Gauri represent two cultural domains recognised by early nationalists as a way of protecting Indian culture, spirituality and tradition from colonialism and European modernity. They are ghar (home), feminine space symbolising tradition and spirituality and bahar (outside) where the masculine must completely confront and adapt to modernity in order to oust the invader. Gauri's space in the film is in ghar, not in purdah (veiled, always enclosed). She can selectively modernise as a 'new woman', but her place in that process is held close to the traditional role of looking after and obeying family or husband and sustaining Indian culture and tradition. In Chatterjee's sense she is 'normal'. Elizabeth joins Bhuvan in bahar, but her role ambiguously slips between ally 
and the 'abnormal' 'she who could be sex object.' The Indian woman signifies nation. She is warned that she must construct herself as superior to and different from the white Western woman (ibid: 129). In this way the white woman's role in Lagaan is instrumental, as a warning, in re-enforcing specific female roles in modernity.

The lure of pleasure is not inconsequential. Pleasure operates at the expense of the white woman. The Indian female audience is invited to enjoy watching Elizabeth suffer the embarrassment of unrequited love, but in doing so, acquiesce to a view of womanhood that is restricted to a 'place of bearer, not maker of meaning' (Mulvey, 1989:15). Elizabeth creates new meaning by rejecting her brother's view of the colonised Indian and acting against his wishes. She gains nothing from this. The white woman is the elephant in the room in modern India. What to do with her influence? In Lagaan she is castrated as an example to Indian women. Her demise, a sort of gladiatorial spectacle, distracts Indian women from the limitations of their expected roles and sends a warning about the consequences of independent action and any expression of sexual autonomy. The white woman represents modernity firmly under the control of masculinity. The ending of the film clearly states that Elizabeth is not free to go into a new life emboldened by her independent stance against her brother. Her gift to India has awarded her something that the makers of the film seem to consider honorable and desirable. Unmarried, perhaps lonely in far away England, she is nevertheless, absorbed as Radha into the Hindu community of females living in bhaktic desire for the male god Krishna, who Bhuvan represents as a filmic avatar.

The use of the white woman as facilitator of success with ambivalent and ambiguous sexual relationships with the Indian male protagonist, recalls the deep psychological, almost psychosomatic terrain of colonialism. This is implicated especially in both the desire for the white woman and the desire to reject her. Albert Memmi warned that the complex interpersonal processes of othering would continue well beyond independence (in Gandhi, 1998:6). Franz Fanon has highlighted this as one of the dynamics of colonialism, where colonised people's response to experiencing racism is one of a fantasy and desire to reclaim self-esteem through sexual relationship with the woman of the coloniser (Fanon, 1968:63). In this context, the woman takes on symbolic cultural value in the contest between colonised and coloniser. 
Lagaan, Rang de Basanti and the advertisement that I will discuss, express this sexual and territorial wound that Fanon identifies. Elizabeth's rejection as an agent of erotic fulfillment could be a response to colonial constructions of the Indian male as both effeminate and sexually rapacious, particularly of white women. The white woman represents the vulnerable body of the coloniser, part of, 'owned' by India's tormentors, but obviously not completely because she shows that she desires relationship with an Indian man. To attract her love, to have her or reject her is a way of mastering power over the coloniser, modernity and Westernisation.

\section{Rang de Basanti}

The film Rang de Basanti: a generation awakens, scripts a white English woman into a similarly catalytic and 'pedagogical' role. Sue arrives in Delhi to make a documentary film based on her Grandfather's diary. The diary records the remorse her Grandfather felt over his part in the torture and execution of the famous revolutionary Bhagat Singh and his fellow Independence fighters during the Raj. Having lost the financial support of her British producer, Sue is forced to work with an untrained cast. With the help of her Indian friend and casting agent, Sonia, she finds the actors for the revolutionaries in a gang of cynical university students at a gathering place called the 'classroom'. DJ, who becomes Sue’s lover, plays Chandrashekar Azad, Sonia plays Dhurga Bhabi, Karan plays Bhagat Singh, Aslam plays Ashfaqullah Khan, Sukhi plays Rajguru and Laxman Pande plays Ramprasad Bismal. In a story within a story scenes of the revolutionaries' violent confrontations with the British are interspersed with the story of making the film. Historical and contemporary time converge in the final dramatic scenes.

This convergence of time is prompted by the death of Sonia's betrothed who dies in an air force plane accident. The discovery that his death is due to corrupt deals in faulty plane parts at Government level becomes the final catalyst for DJ and Sonia and the others to take desperate action. They stage a protest which is brutally attacked by police. The mother of the dead pilot is beaten into a coma and lies in a hospital bed for the rest of the film. They then kill the defence minister. When they realise that this act alone won't change anything, they hijack All India Radio station and broadcast their confession and political rationale for murder around the nation. The police are sent in and we see in graphic detail DJ and his friends (Sonia is absent) killed as the nation 
listens. Around the nation shocked students and civilians respond by vowing to end corruption.

Rang de Basanti (English title: Colour it Yellow or Give me Saffron) is a film aimed at young people in urban areas, specifically upper middle-class college students. Significant changes are occurring amongst these people and spreading out into the less well off urban youth. A recent Indian study has found that, 'it is time to shed the traditional misconceptions about the rarity of premarital partnership formation or sexual activity among young people’ (Jejeebhoy, 2006:ix). Absent from the film is any sign of effective parental control or restrictions on the social mixing of young men and women. The film is ambiguous, however, as to whether this should be interpreted as liberating for women or simply that through the adoption of Western life styles, young women's bodies are now available for young Indian men. It is the masculine in the film that claims modernity and processes of Westernisation for itself with the female body cosmetically framing maleness.

What is the white woman doing in this film? To answer this question I will follow the subtexts that reveal deeper stories, desires and conflicts that run beneath the grander narratives of political awakening and renunciation. These subtexts embellish the story as sentiments and desires that help the film find its audiences. They exist in the sexualised play between Sue and DJ and the spatial placement of the women in the film. As in Lagaan they are concerned with selective adoptions of modernity for women.

Through her placement as a moral authority, Sue acts as a catalyst for unity and entrenches gender roles. Her placement as a love/sex object regenerates hyper masculinity by implying that sexual kudos and power can be gained via a relationship with the white Western woman.

The white woman's crossover role is not only located in East and West, but in traditional life and modernity. This conforms to the Bollywood style often referred to as 'masala films, mixed and spicy', that aim to please a wide audience for box office returns (Dwyer, 2002:178). The film seems to expresses a desire for national unity. There are, however, shades of gray that compete within the film. 
Sue is given moral authority in her choice to make a film about Bhagat Singh rather than Mahatma Gandhi, her English producer's preference. The disagreement recalls pre and post-independence tensions between nationalist and political groups which favoured militancy and those who supported pacifist Gandhian non-violence. The Hindu right has commandeered Singh to their cause, as Ashis Nandy says, 'because of his militancy' (Nandy, 1998:32). The film reclaims Singh as a Sikh and a socialist, but ignores his atheism. Sue's role here links her to a preference for violence and possibly, religious fundamentalism. The English translations of the film's title reinforce this feeling. Basant literally means spring, with the added $i$ in some dictionaries changing its meaning to yellow or saffron, the colour of Hinduism. Saffron has been taken up by contemporary Hindu extremists groups like the Shiv Sena and others to symbolise their cause for a dominant sectarian Hindu India.

In the process of making her film, Sue convinces the cynical young men to relate to the revolutionary passion of their characters. She resolves conflict within the group over communalist (inter-religious) rivalry and polarisation between anti-Westernisation versus Westernisation. The cast is united in its diversity (Sikh, Hindu, Muslim, sectarian, secular, pro-Western, anti-Western). Her saffron placement is mitigated by the trope of unity.

Sue has exclusive narrative connection to us, the audience. We hear her interpretation and response to events. She is set up as representative of the 'good' West in juxtaposition to bad corrupt India. She knows about morals and ethics. In anger she asks, 'Why did I come to a country where everyone is just looking for an excuse to fight' and in consternation, 'was that a bribe?' In a playful scene, Sue insists that 'tradition is important' when Sonia refuses to touch the feet of her fiancé. Here we have the first hint that her role as moral authority will cross into concerns about modernity and tradition for Indian women. This scene heralds the way the film ends for Sonia.

Sue's role in enforcing and generating masculine kudos begins in the 'classroom'. It looks like an ancient amphitheatre where young men and women carry out some very Western adolescent activities: graffiti writing, listening to Western music, heavy drinking. The film immediately establishes that this is a rebellious space. Young beautiful women frame young men doing heroic stuff. Here, Sue first meets her cast and 
in particular her future lover DJ. The perception of Sue and Sonia as independent, professional and quite autonomous women blurs when they begin to interact with their male counterparts in the classroom. We see this when DJ meets Sue. Obviously the leader of his pack he takes possession. He sums her up and voices his approval, while she meekly stands with head somewhat bowed, embarrassed, but flattered. (The nineteenth century painting, The Slave Market by Jean-Leon Gerome, comes to mind.) At this point and in subsequent scenes we learn that Sue is attractive to Indian men. As she dances with the pelvic thrusting DJ, answering the Althussian 'call', she begins to slide back into that vamp role and, in reference to The Slave Market and the Rowlandson cited previously, into her past Orientalist framing. This becomes clear when we see how unimportant Sue's actual completed film is beyond its facilitation of national political awakening. Sue is now interpellated into the theme of romance. This thinly disguises the real reason for her presence in the film which is to provide a place, her body, on which Indian male pride and power can regenerate itself.

The making of Sue's film, in a whirl of editing, magically happens somewhere underneath a lot of machismo posturing, fast bikes and traditional displays. These scenes could easily be tourist advertisements luring young English travellers to carefree India. Sue is advertising material, her body enhancing the forms of bikes, the byways of happy village India and powerful male Indian bodies.

Sue and DJ are not soul mates because that would require reciprocal interest in each other. Apart from DJ's eventual cooperation in her film and their mutual sexual interest, the relationship is all about DJ and Indian masculinity. His development into an Indian Hero is paramount as he moves through his encounter with the modern Western woman who has some things to teach Indians about themselves, their past and their responsibilities. The demonic underside of this encounter is felt in an odd oracular moment when Sue's reflection is caught looking into a photograph of the father of the soon to be dead pilot, who also died serving his nation. Is she seeing the future, is she the catalyst for the death that is about to overtake the lives of so many? Or is she the face of a past, present and future that has merged colonialism and European modernity into a corrupt and violent internal neocolonialism? This is a self-reflective moment for Sue, a moment when she could ask, 'what am I doing here, who or what am I here?' This short scene links her to death, and death is what follows in the film. 
Sue's actual film work fizzles out ambiguously after the death of the pilot. Overtaken by events, it was clearly only meant to be a device for the facilitation of political awakening, expressing frustration over the lost dreams of postcolonial India. As DJ and his friends are embroiled in their violent destiny, Sue slips into the background. In growing panic, she visits DJ's mother and the comatose pilot's mother. Sue's role could be understood to end here as the catalytic outsider prevalent in Western cinema. I would argue that Sue has been placed in a different space, which I will endeavor to show below.

When DJ and his friends are slaughtered by police in All India Radio station, the dead pilot's mother begins to stir, a tear runs down her face and she opens her eyes. The audience at this moment will be drawn into the powerful political and national symbol of Bharat Mata (Mother India). Nandy has noted the Indian belief that, 'woman as an object and source of sexuality was inferior to woman as a source of motherliness and caritus' (1983:54). Is this still the case? The dramatic linking of the Mother awakening with the death of the young men and the eruption of public outcry, seems to push Sonia and Sue, as modern women, further into the discourse of nationalism and patriotism that prioritises the Mother and excludes as 'abnormal' the woman who is modern, Western and can be a sexual object.

In the next scene the camera action says much abut Sonia's place in the future. The two women are sitting on the wall of an ancient ruin, Sonia, the Indian woman, is not speaking. Sue speaks for both of them. The camera steadily moves past Sonia draped in widow white and focuses entirely on Sue, excluding Sonia. Sue says, 'we often return to this place', overlooking the airstrip where DJ and his friends once chased planes as they took off. All she can hear is laughter, not words. This scene recalls Chatterjee's observation that nationalist discourse tends to speak about and for women, rather than give women voice (1993:133). The future does not speak to Sonia as it does to her male counterparts. In the last scene of the film a young Bhagat Singh asks his father what he is doing. His father replies, that he is 'planting a mango tree so thousands of trees can grow', the trees, no doubt, symbolising future generations of revolutionaries. The ghosts of the dead heroes, DJ and his friends look on, smiling their encouragement to the young boy. That Sonia in Sue's film played the revolutionary Durga Bhabi, but is not represented in this last scene of the film, seems to support my thesis. As a modern 
women, she is sidelined, not engaged in the social and political world either inside or outside. She represents deselected aspects of modernity.

There are two ways to interpret her placement on the outside; both are ambivalent within the film. One, is that Sonia's character relates to the Bollywood revenge films of the 1970s, where a male outsider is supported by an outsider female in their confrontation with corrupt authority. Although Sonia encourages the men to do their violent deed, she differs from the earlier strong women in that she does not take part (Basu et. Al., 1980:63). The second is concerned with the traditional gender roles, adopted by nationalism, that are spatially represented by the concepts of the inside as feminine, the house, ghar, family and outside bahar as masculine, in social and political life. Sue has a room at the university. Sonia has nowhere of her own. This 'outsideness' is exacerbated by the absence of family around Sue and Sonia. Sonia has absolutely no family underpinning in the film.

While being in the outside could represent modernity and an acceptance of social roles for women, the lack of family and home undermines this with a suggestion of powerlessness, loss of role and connection to nationhood. In traditional India, for women, being outside, single, widowed and without family is unacceptable in most Indian communities. In this situation women can find themselves ostracised and vulnerable. Most Indian people who see this film will be sensitive to this issue, while a Western audience might not notice. The Western woman can be left safely in this position, but the Indian woman would have to correspond to a type. Sonia, an Indian woman with a Western name could be read as a reference to the vamp role, so prevalent in many Hindi films. She is also modern and Westernised and in Chatterjee's thesis, 'abnormal' and not upholding nationalist values of the feminine. From this point of view, unattached Sonia and Sue are juxtaposed against the powerful Mother, whose awakening (in a very modern hospital) makes a link with the future expressed in the subtitle of the film, A Generation Awakens. Another connection to the symbolism of mother in the film, is that both DJ's mother and the dead pilot's mother are strongly associated with inside places: home, temple and hospital, re-enforcing traditional and nationalist concepts of femininity as ghar, alluding to sacrifice and spirituality. 
The spatial and narrative placement of the feminine at the end of the film recalls long held nationalist concerns with the role of women in modernity and Westernisation. There is a definite split between masculine and feminine activity. Sue's active role in the group fades after her pedagogical role is supplanted with the death of the pilot and the subsequent revenge. Sonia does not take part in the murder or the final act of defiance by DJ and the other men. In the last scenes of the film she is also distinctly separated from nationalism, symbolised by the awakening Mother.

Throughout the film, until she is linked to death, Sue, as symbolic of European modernity and power, is made adjunct to Indian male power. Unlike Elizabeth in Lagaan, she is not rejected as a possible partner, although it could be argued that death and the resurrection of the mother as a nationalist sign of nation displace her. Both Sue and Elizabeth are held in place for further use. They are not outsiders but integral parts to the structuring of modernity, being what the Indian woman must create herself in opposition to. Elizabeth as an English Radha is held by her lifelong desire for Bhuvan. Sue is left sitting on the wall of a ruin, suggesting that she will be called again to right the wrongs of her forebears.

Throughout both films the white woman is there because of something that clearly is revealed in the advertisement that I will discuss below, and that is an attempt to construct male kudos by associating with and dominating that supreme symbol of Western freedom and power, the blonde white woman.

\section{Killerjeans}

In an advertisement for a clothing company called 'Killerjeans', a young Indian man lies on his back on the floor. His head is turned and he looks at the viewer. His eyes and the languor of his body have the affect of someone whose desires have been satiated. In his right fist he holds a handful of blonde hair belonging to a young white (or made to look white) woman. She could be dead. Her head rests on his shoulder, her torso disappearing off to the right hand side of the image. Directly behind this scene, the same young woman is shown from the waist down. She stands holding a sword in front of her that descends from in front of her crotch to the floor. Off to the left she appears again, 
also the lower half of her body, this time lying down with one leg bent, knee pointing to the ceiling.

This image can be read as a story. Like a film, it intends to engage the imagination and suggests the ambivalence and disquiet in India about Westernisation and modernity. The Western white woman is both exciting in her individuality and availability as well as dangerous, especially as a potentially destabilising influence on the traditional role of women and family in India. The young man has to tame her as the primary threat to his traditions. In an article on the mediating and balancing role that Bollywood films play between tradition and narcissistic Westernisation and modernity in India, Madhu Kishwar states, 'People in non-Western cultures feel threatened by this kind of individuality because it undermines traditional institutions, especially the family’ (2004 p.2).

By possessing and dominating the white woman, the young Indian male can dream himself into dominating and controlling modernity rather than being controlled by it. The white woman is used in this scene because it would be sacrilegious to the ideal of Indian womanhood to suggest that she is available to the young Indian man in this way. It is possible to stage the white Western woman in this role because this is how Western media represents her.

The similarity between this advertisement and Rang de Basanti is clear. There is a voyeuristic focus on Sue's body and she is shown physically close to DJ. There is a full lip kiss and close sexual dancing, as well as those scenes that resemble travel brochures. We don't see Sonia presented in this way, suggesting the use of the Western woman to construct a hyper-sexed masculinity as an attempt to confirm power and control.

Both films and the advertisement hark back to pre-independence recreations of masculinity. In the ambivalent relationship between the colonised and the coloniser, there is the desire both to be like the other and to reject the other. Nandy suggests that a defensive psychological change occurred amongst Western educated Indians as a response to colonialist stereotyping of the Indian male as effeminate. This resulted in an extreme separation of feminine and masculine (1983:8). In this way certain sections of the nationalist movement began to model themselves on their colonial oppressor, 
favouring English concepts of manliness as 'aggression, achievement, control, competition and power' (ibid: 9). The feminine must be clearly delineated and controlled.

Coupled with Chatterjee's thesis that the 'woman as nation' is de-sexed and glorified as mother and goddess, we see male enthrallment with woman as mother merge with a suspicion held by men that the feminine signifies weakness and is enervating to masculine power. The result is sexual repression and shame imposed on women. For men there is the fear of losing power and control along with feelings of shame when confronted with their sexual desire for a woman. In this way, the white woman's role becomes more insidiously apparent, and a division, not just between masculine and feminine, but between love, respect and sex becomes clear. This is the area that the white woman occupies, suspended outside the two fixed positions of ghar and bahar, 'normal' and 'abnormal', as the whore and the good or powerful woman as ally. By placing the white woman in this unstable dichotomous role she is useable as a sexual object. Normal concerns over feminine morality can be ignored. The white woman relieves the sexual repression caused by the moral injunction held in defensive nationalist gender constructions that the wife and the mother cannot be those who could be sex objects. She, as representative of modernity, can briefly take on a position of equality with the Indian male in her role as enabler without threatening his masculinity. Because the white woman is outside Indian tradition, none of these roles either threatens that tradition or his power. She can be dispensed with once she has fulfilled his or the nation's needs.

\section{Conclusion}

The white woman's role in Lagaan and Rang de Basanti seems to have been, for the most part, critically overlooked. Apart from Farred's detailed contribution, I have found only three writers in the fields of film and social criticism who have very briefly questioned or commented on her role. K. Hariharan, wonders at the presence of Elizabeth in Lagaan and the prevailing fixation on white skin in India (2002:1). Siriyavan Anand is perplexed that in 1893 under the Raj there is no consternation over a white woman training an Indian cricket team. He questions ironically, why the inclusions and role reversals: Hindus teaming with Sikhs, Muslims and Dalits, could not 
have included women (2002:4). On the scripting of a white English woman as the catalyst for political awakening in Rang de Basanti, a blogger, called Yeti, sees only internalised racism and colonialism (2006). Aarti Wani cannot take seriously the claim that Rang de Basanti is a revolutionary film as it ignores the daily reality of the protest and struggle of farmers, tribal people and workers. She says it is about upper middle class college students who will benefit from the system most. 'The truly exploited majority is always already forgotten' (2007:4). And what about women?

In this paper I have tried to show how the white woman as the partner conscripted into the Orientalist tableau of the sexually deviant, dangerous and effeminate Indian male, has been brought 'home' to her Indian counterpart. In the wishful fantasy world of these films and advertisement she proves his innocence and helps him to reclaim power. In her role as facilitator, moral authority and sex object it is hoped that she can bring back wholeness. She is currency as marked by her association with the power of Western modernity and capitalism and in her use as an object of desire and derision between colonial power and colonised as the means through which each side can denigrate and psychically undermine. She affirms masculine dominance and nationalist constructions of gender. The fact that her role is critically overlooked by Western and Indian critics alike suggests Lacan's reversal of the Cartesian phrase: 'I think therefore I am', into 'I think where I am not, therefore I am where I do not think' (in Gandhi, 1998:9). In other words, the critical neglect of the role that the white woman plays suggests our contemporary and universal reluctance to see how the self is situated in processes of oppression, exploitation, expediency and abnegation.

\section{Bibliography}

Anand, S. (2002) 'Eating with Our Fingers, Watching Hindi Cinema and Consuming Cricket.' Himal South Asian. <www.himalmag.com/2002/march/essay.htm> (2.10.05).

Basu, S., Kak, S. \& Krishen, P. (1981) 'Cinema and Society: A Search for Meaning in a New Genre', in Indian Popular Cinema: Myth, meaning and metaphor (ed.) Pradip Krishen India International Centre Quarterly Special Issue. Vol.8(1) New Delhi: India International Centre.

Chatterjee, P. (1993) The Nation and its Fragments: Colonial and Postcolonial Histories. New Jersey: Princeton University Press. 
Dwyer, R. (2002) 'Real and Imagined Audiences: Lagaan and the Hindi Film after the 1990’s.’ Etnofoor Anthropological Journal. Issue: 15(1/2): 177-193, available online: <www.etnofoor.nl/frameset.htm> (8.4.07).

Fanon, F. (1968) Black Skin White Masks. New York: Grove Press.

Farred, G. (May 2004) 'The Double Temporality of Lagaan: Cultural Struggle and Postcolonialism', Journal of Sport and Social Issues. Vol. 28 (2) Sage Publications. <jss.sagpub.com> (4.10.05).

Gandhi, L. (1998) Postcolonial Theory: A Critical Introduction. New Delhi: Oxford University Press.

Ghosh, S. (1999) 'Feminists Engage with Censorship' in Brosius, C and Butcher, M. Image Journeys: Audio visual media and cultural change in India. New Delhi: Sage Publications.

Gokulsing, K.M. and Dissanayake, W. (1998) Indian Popular Cinema: A Narrative of Cultural Change. New Delhi: Orient Longman.

Hariharan, K. (May 2002) 'Mirror, Mirror on the Wall: Being Fair is not Unfair after all.’ In webzine, <www.littleindia.com> (6.10.05).

Jayawardena, K. (1995) The White Woman's Other Burden: Western Woman and South Asia during British Colonial Rule. New York: Routledge.

Jejeebhoy, S. J. et al (2006) Formation of partnership among young women and men in Pune district, Maharashtra. New Delhi: Population Council. $<$ www.popcouncil.org/asia/IndiaRI.html> (4.4.07).

Kishwar, M. (June 2004) 'The Idea of India', India Together. $<$ www.indiatogether.org/manush/issue139/idea.htm> (7.11.05).

Mulvey, L. (1989) Visual and Other Pleasures. Bloomington: Indiana University Press.

Nandy, A. (1998) Creating A Nationality: The Ramjanmabhumi Movement and Fear of the Self. New Delhi: Oxford University Press.

(1983) The Intimate Enemy: Loss and Recovery of Self Under Colonialism. New Delhi: Oxford University Press.

Pollock, G. (1987) 'What's Wrong with Images of Women?' Parker, R. and Pollock, G. (eds.) Framing Feminism: Art and the Women's Movement 1970-1985. London: Harper and Collins.

Schick, I.C. (1999) The Erotic Margin: Sexuality and Spatiality in Alterist Discourse. London: Verso.

Wani. A. (2007) 'Uses of History: Rang de Basanti and Lage Raho Munnabhai.' Mr Zine Monthly Review. <www.mrzine.monthlyreview.org/wani120207.html> (6.4.07).

Yeti. (2006) '45 Minutes of Rang de Basanti.' Cultural Sabotage. $<$ www.culturalsabotage.blogspot.com/2006/03/review> (5.4.07).

\section{Films}


Lagaan: Once Upon a Time in India. Prod: Aamir Khan.Dir and writer: Ashutosh Gowariker. Cast: Aamir Khan, Gracy Singh, Rachel Shelley. India 2001.

Rang de Basanti: A generation Awakens. Prod: Ronnie Screwvalla, Dir: Rakeysh Omprakesh Mera.Writer: Kamlesh Pandey. Cast: Aamir Khan, Soha Ali Khan, Sue Patten, Waheeda Rehaman, Siddharth Narayan, Kunal Kapoor, Atul Kulkarni, Madhavan. India 2006. 